\title{
A new marine cyclopoid copepod of the genus Neocyclops (Cyclopidae, Halicyclopinae) from Korea
}

\author{
Jimin Lee', Cheon Young Chang ${ }^{2}$ \\ I Biological Oceanography \& Marine Biology Division, Korea Institute of Ocean Science \& Technology, Ansan, \\ Korea 2 Department of Biological Science, College of Natural Sciences, Daegu University, Gyeongsan, Korea \\ Corresponding author: Cheon Young Chang (cychang@daegu.ac.kr)
}

Academic editor: Danielle Defaye | Received 7 April 2015 | Accepted 28 August 2015 | Published 16 September 2015

http://zoobank.org/C8539555-E85F-4C6A-A935-9D351A878A94

Citation: Lee J, Chang CY (2015) A new marine cyclopoid copepod of the genus Neocyclops (Cyclopidae, Halicyclopinae) from Korea. ZooKeys 520: 131-146. doi: 10.3897/zookeys.520.6006

\begin{abstract}
A new cyclopoid species of the genus Neocyclops Gurney, 1927 is described. Type specimens were collected from a beach on south-western coast of the Korean Peninsula by rinsing intertidal coarse sandy sediments. Neocyclops hoonsooi sp. $\mathbf{n}$. is most characteristic in showing the conspicuous chitinized transverse ridges originating from the medial margins of the coxae of all swimming legs. The new species is most similar to $N$. vicinus, described from the Brazilian coast, and $N$. petkovskii, from Australia. All three species share a large body size (more than $750 \mu \mathrm{m}$ long), the presence of an exopodal seta on the antenna, two setae on the mandibular palp, the same seta/spine armature on the third endopodal segment of leg 3 (3 setae +3 spines), and the fairly long inner distal spine on the third endopodal segment of the female leg 4 . However, $N$. hoonsooi sp. n. differs from both species by the much shorter caudal rami (less than 1.7 times as long as wide) and the shorter dorsal caudal seta VII. Furthermore, $N$. hoonsooi is clearly distinguished from $N$. vicinus by the 10-segmented antennule (vs 12 segments in $N$. vicinus), and from $N$. petkovskii by the elongate inner distal spine on leg 5 exopod and the 3-segmented leg 5 in male (vs 4-segmented in $N$. petkovskii). A tabular comparison of characters separating $N$. hoonsooi from its closest allies and a key to Neocyclops species from the Indo-Pacific Ocean are provided. This is the first record of the genus Neocyclops from the northern Pacific.
\end{abstract}

\section{Keywords}

Beach, description, interstitial, meiofauna, northwest Pacific, taxonomy

Copyright Jimin Lee, Cheon Young Chang. This is an open access article distributed under the terms of the Creative Commons Attribution License (CC BY 4.0), which permits unrestricted use, distribution, and reproduction in any medium, provided the original author and source are credited. 


\section{Introduction}

Members of the genus Neocyclops Gurney, 1927 (Cyclopidae, Halicyclopinae) typically inhabit marine epibenthic or interstitial environments. The genus is widely distributed in coastal, surface and subterranean (anchialine) habitats of the Northeast and Tropical Atlantic, the Mediterranean, the Black and Red Seas and the Indo-Pacific (West Australia, Papua New Guinea), with an endemism index of about 95\% (Pesce 2015). Karanovic (2008) recently revised the genus and added 11 new species, including eight interstitial species from Australia. However, notwithstanding its wide distribution and potentially high diversity, the taxonomy of the genus is in a state of disarray. The primary reasons for this state of affairs are the paucity of useful diagnostic characters to differentiate most species (due to the very conservative morphology within the genus), the significant variability displayed by some of them and the inadequate descriptions of several previously described species (Karanovic 2008). The genus currently accommodates 24 nominal species but it is known that many as yet unnamed species await description (Karanovic 2008, Walter and Boxshall 2015, Pesce 2015).

Although cyclopoid copepods constitute an important component of the marine epibenthic and interstitial fauna, our knowledge of their taxonomy and diversity is relatively very poor in comparison with freshwater cyclopoids, especially in the northwest Pacific region (Chang 2011, Karanovic 2014). Chang (2011) recorded a new species of the genus Cyclopinoides Lindberg, 1953 (Smirnovipinidae) from the Korea Strait (Tsushima Island, Japan and Busan, Korea), and recently Karanovic (2014) described a new species of Euryte Philippi, 1843 (Cyclopidae) from the East Sea (Sea of Japan). During field surveys of the marine interstitial cyclopoids from Korea, a new species of the genus Neocyclops was found in a beach on the south-western coast of the Korean Peninsula, representing the first record of the genus from the North Pacific. In this paper we provide a detailed illustrated description of both sexes, including a tabular comparison of the salient characters distinguishing the new species from its closest congeners.

\section{Materials and methods}

Collections were made at Holtong beach, located along the south-western coast of the Korean Peninsula, in shallow littoral (about $0.5-1 \mathrm{~m}$ deep) by scooping the surface layer of a coarse sand bottom with a long-handled dipper. Sediment samples were gathered into a bucket, subjected to freshwater shock and filtered through a conical plankton net or plankton hand-nets (mesh size $64 \mu \mathrm{m}$ ). Samples were immediately fixed in the field by adding a few drops of $35 \%$ formaldehyde. Copepods were sorted in the laboratory, using a micropipette under a zoom-stereomicroscope (Zeiss SV-11, Germany), and transferred to $80 \%$ ethanol or to $4 \%$ buffered formaldehyde for long-term preservation.

Methods for dissection, double-coverglass preparation using H-S slides (see Shirayama et al. 1993), drawing and measurements followed those outlined in Chang $(2013,2014)$. 
Type specimens are deposited in The Natural History Museum, London (NHMUK) and the specimen room of the Department of Biological Science, Daegu University (DB), Korea.

General terminology for the description of the new species follows Huys and Boxshall (1991). Abbreviations used in the text, table and figure legends follow the conventional ones frequently used in the taxonomy of copepods: enp- 1 to enp- 3 or exp-1 to exp-3, the first to third endopodal or exopodal segments of each leg. Sewell's (1949) system is adopted for seta/spine armature of legs 1-4, where setae are denoted by Arabic numerals, and spines by Roman numerals (Tran and Chang 2013, for details cf. Huys and Boxshall 1991, fig. 1.5.7).

\section{Systematic accounts}

\section{Family Cyclopidae Rafinesque, 1815 \\ Genus Neocyclops Gurney, 1927}

\section{Neocyclops hoonsooi sp. $\mathbf{n}$.}

http://zoobank.org/451980E9-A08A-4365-8240-7A185C4877C6

Figs $1-4$

Type locality. Holtong beach $\left(35^{\circ} 03.68^{\prime} \mathrm{N}, 126^{\circ} 19.87^{\prime} \mathrm{E}\right)$, South Korea, Jeollanamdo Province, Muan-gun County, Hyeongyeon-myeon, Oryu-ri; western coast of the Dadohae Oceanic National Park, South Korea.

Material examined. Holotype $q$ (DB20046), allotype ô (DB20047), both dissected on slides. Paratypes: 1 ( (NHMUK reg. no. 2015. 3056), $10^{\Uparrow}$ (NHMUK reg. no. 2015. 3057), both undissected, ethanol-preserved; 2 우 (DB20048, 20049), $1 \delta^{\lambda}$ (DB20050), dissected on slides; 2 우 (DB20051), $2 \hat{\jmath} \widehat{\partial}^{\lambda}$ (DB20052), in ethanol. All specimens were collected from the type locality by J. Lee on 21 August 2008.

Diagnosis. Female habitus large, about $830 \mu \mathrm{m}$ long. Genital double-somite with lateral expansions in anterior quarter. Caudal rami about 1.7 times as long as wide, with 7 caudal setae, including vestigial ventrolateral seta I; inner caudal seta VI well developed, about 1.7 times longer than outer caudal seta III; dorsal seta VII slightly shorter than caudal ramus. Antennule 10-segmented. Antenna with exopodal seta. Exp-3 of legs 1-4 with setal formula 5,5,5,5 and spine formula 3,4,4,3; enp3 of leg 3 bearing 3 spines and 3 setae; inner distal spine on enp- 3 of leg 4 distinctly longer than enp-3 and outer distal spine. Leg 5 exopod subpyriform, about twice as long as wide; inner distal spine 1.2 times longer than outer spine, about 1.4 times as long as lateral spine, about 0.9 times as long as exopod. Male caudal rami 1.36 times longer than wide, with 7 caudal setae. Male leg 5 3-segmented, comprising coxa, basis and exopod.

Description. Female (Holotype). Body (Fig. 1A) large and robust, $830 \mu \mathrm{m}$ long, (mean $826 \mu \mathrm{m}$, standard deviation 12, $n=6$ ), excluding rostrum and caudal setae. 


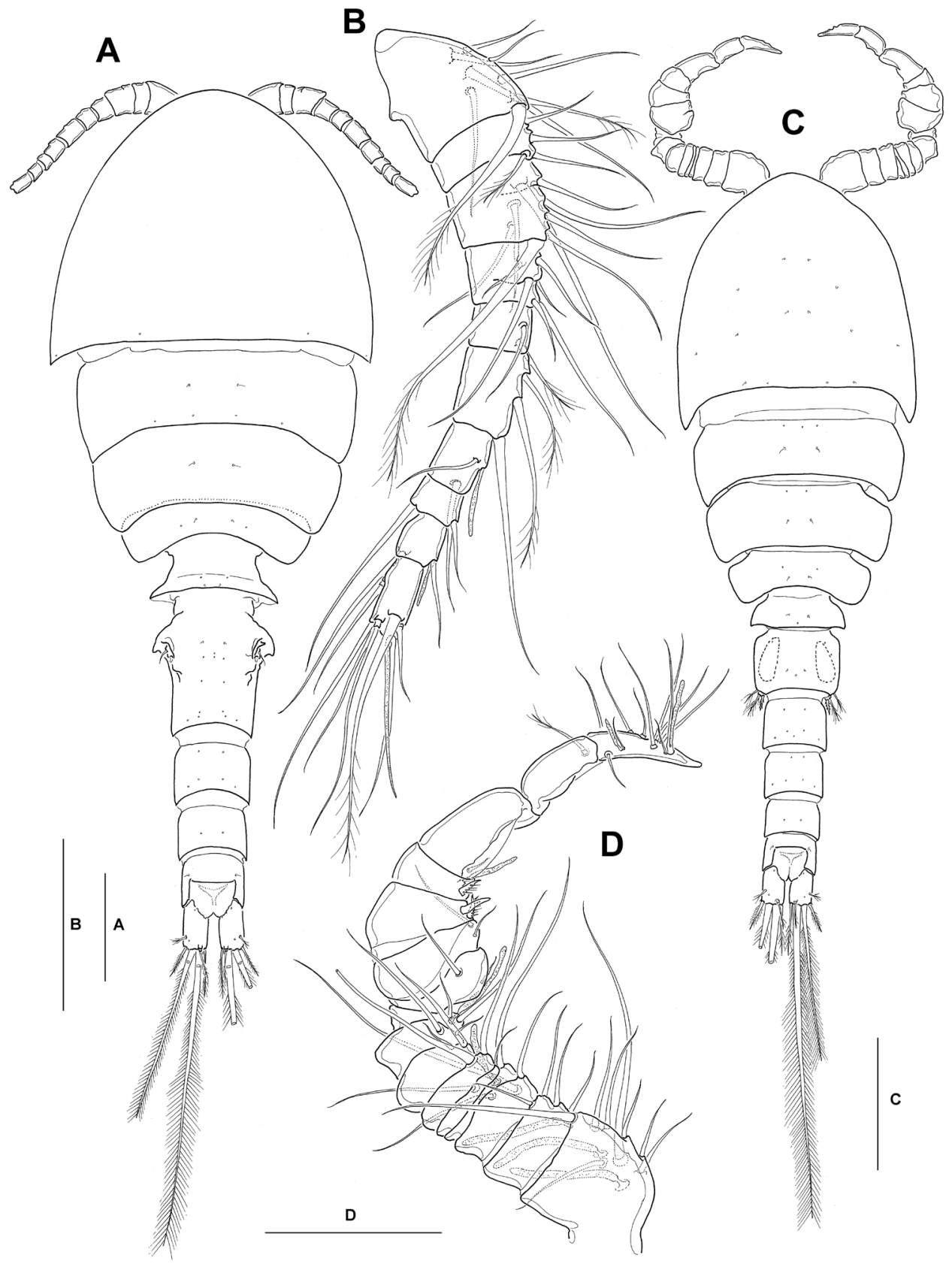

Figure I. Neocyclops hoonsooi sp. n. A-B female: A habitus, dorsal B right antennule, dorsal. C-D male: C habitus, dorsal D left antennule, dorsal. Scale bars: $100 \mu \mathrm{m}(\mathbf{A}, \mathbf{C}), 50 \mu \mathrm{m}(\mathbf{B}, \mathbf{D})$. 
Body width $303 \mu \mathrm{m}$, greatest width at posterior margin of cephalothorax; body length/ width ratio about 2.7. Color of preserved specimens a milky white tinge.

Prosome oval, about 1.2 times longer than urosome, a little protruding anteriorly. Rostrum reflexed downwards, not discernible in dorsal view, with blunt apex in ventral aspect. Nauplius eye not discernible. Cephalothorax not strongly protruding anteriorly, slightly longer than 4 free thoracic somites combined; first pedigerous somite completely incorporated into cephalosome. Prosomites not showing pronounced lateral expansions, with narrow and nearly smooth hyaline fringe along posterior; ornamented with one pair of minute sensilla medially on dorsal surface of second to fourth pedigerous somites, and a few integumental pores near posterior margin of each prosomite.

Urosomites (Figs 1A, 2B) length ratios, beginning with fifth pedigerous somite, 36: 100: 43: 39: 43; with hyaline membrane along posterior margins both dorsally and ventrally; spinule rows lacking, except for anal somite with about 20 minute spinules along ventral posterior margin; arrangement of cuticular pores as shown in Figs $1 \mathrm{~A}, 2 \mathrm{~A}$ and $2 \mathrm{~B}$. Fifth pedigerous somite slightly narrower than genital double-somite, ornamented with paired middorsal sensilla; posterolateral corner pronounced. Genital double-somite slightly longer than broad, with paired backwardly directed spinous processes in anterior quarter; leg 6 represented by one seta and one small cuticular projection surrounded by cuticular wrinkles dorsolaterally. Copulatory pore small, located midventrally in about proximal quarter of genital double-somite; seminal receptacle fully fused medially; both lateral sides transversely undulating, as shown in Fig. $2 \mathrm{~B}$. Anal somite much shorter than wide, about 3/4 times longer than caudal rami; 1 pair of dorsal sensilla just anterior to lateral corners of anal operculum. Anal operculum (Fig. 2A) situated at halfway the anal somite length, not strongly convex with smooth posterior margin.

Caudal rami (Fig. 2A, B) nearly parallel, with 7 setae; ramus 1.68 times (ranging from 1.64 to 1.72 , standard deviation $0.04, n=6$ ) longer than wide, in ventral view, slightly shorter than anal somite; dorsal and medial surfaces of rami smooth, without hairs along inner (medial) margin; outer margin nearly smooth, not interrupted by indentations or spinules. Anterolateral seta I vestigial, represented by minute setule, situated in anterior part of ventral surface (Fig. 2B). Lateral seta II located slightly dorsally, issuing from about distal quarter of outer margin of ramus. Outer seta III short, spiniform and bipinnate, about 0.7 times as long as ramus, a little less than $2 / 3$ length of inner seta VI, surrounded by 3-5 minute spinules at base. Terminal setae IV-V with fracture planes, bipinnate. Inner seta VI well developed, plumose, about 1.2 times as long as caudal rami, about 1.7 times longer than outer seta III. Dorsal seta VII slender, plumose, about 2/3 times as long as inner seta VI, and slightly shorter (0.9 times) than caudal ramus.

Antennule (Fig. 1B) short, reaching to about middle of cephalothorax; 10-segmented; segments 3 and 5 with incomplete ventral and dorsal sutures, respectively, indicating original subdivision. Setal formula: 1-[8], 2-[4], 3-[2+6], 4-[4+2], 5-[2], 6-[3], 7-[2+1 aesthetasc], 8-[2], 9-[2+1 aesthetasc], 10-[7+1 aesthetasc]. 


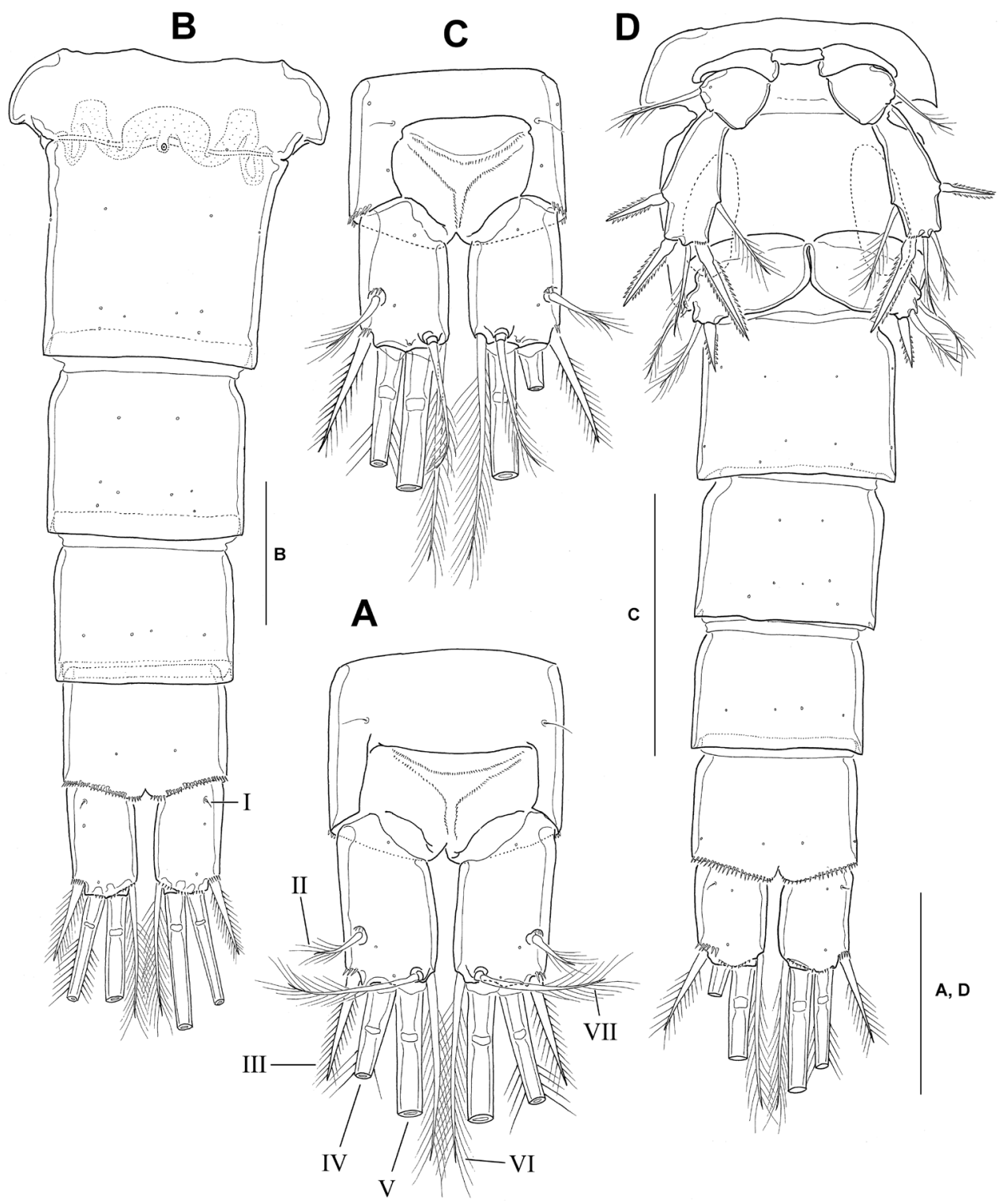

Figure 2. Neocyclops hoonsooi sp. n. A-B female: A urosome, ventral B anal somite and caudal rami, dorsal. C-D male: $\mathbf{C}$ anal somite and caudal rami, dorsal $\mathbf{D}$ urosome and leg 5, ventral. Scale bars: $50 \mu \mathrm{m}$.

Antenna (Fig. 3A) slender, distinctly 4-segmented, comprising coxobasis and 3 -segmented endopod. Coxobasis about 2.1 times as long as wide, with 1 long outer seta distally (unipinnate proximally and plumose distally), representing exopod, and 2 unipinnate setae at inner distal corner. First endopodal segment about 1.7 times as 


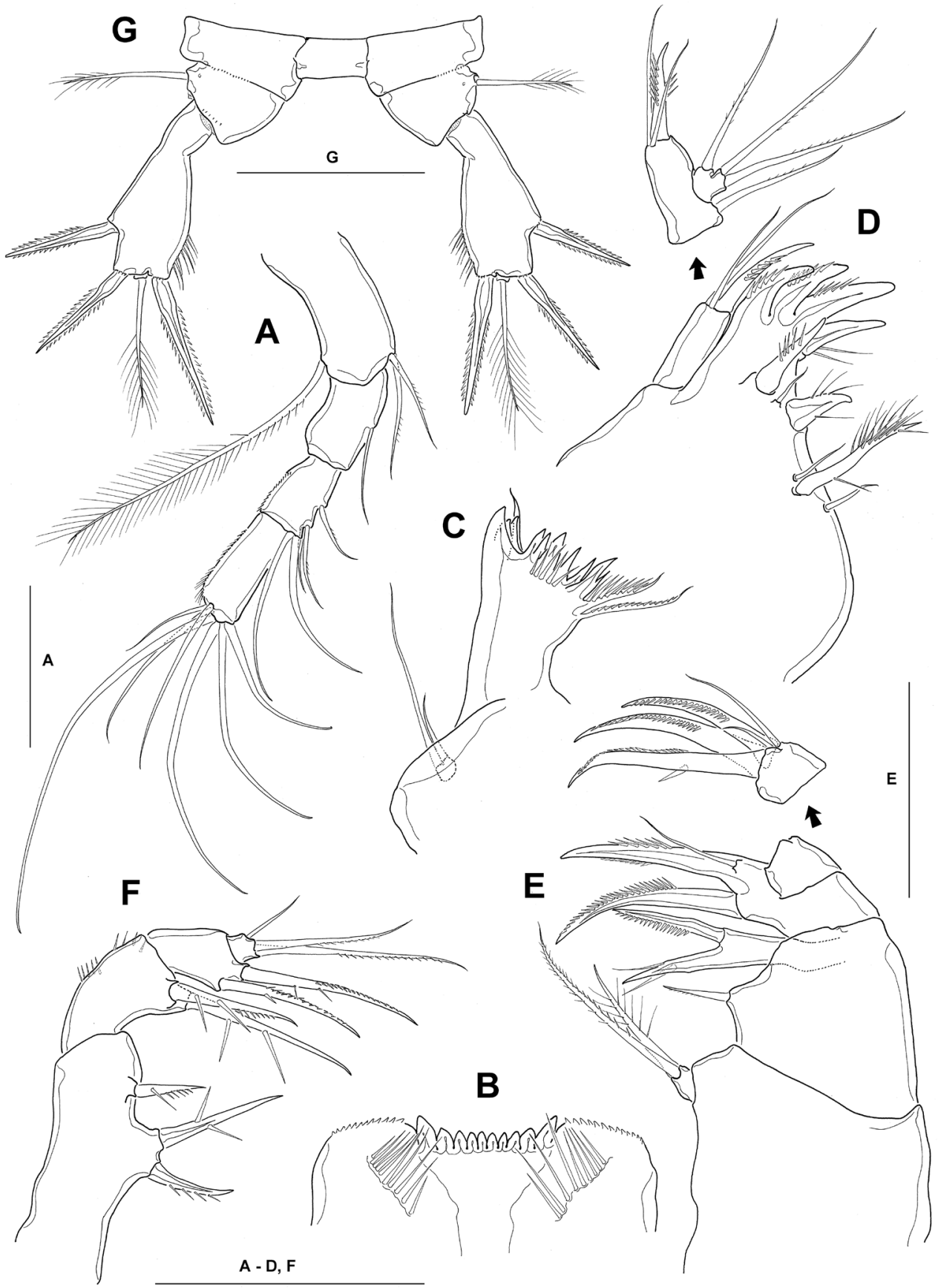

Figure 3. Neocyclops hoonsooi sp. n., female. A antenna B labrum $\mathbf{C}$ mandible $\mathbf{D}$ maxillule $\mathbf{E}$ maxilla F maxilliped $\mathbf{G}$ leg 5 . All scale bars: $50 \mu \mathrm{m}$. 
long as wide, with 1 naked seta at halfway the inner margin. Second endopodal segment small, about 1.5 times as long as wide, with minute spinules along outer margin; armed with 1 short medial, 2 short subapical and 2 long apical setae along inner margin. Third endopodal segment elongate, about 2.5 times as long as wide, ornamented with 1 spinular row along outer margin, bearing 7 apical setae including 4 geniculate and 3 slender setae.

Labrum (Fig. 3B) trapezoidal, armed with 10 strong teeth on broad, slightly concave cutting edge; serrated along distolateral margins; posterior surface with 2 oblique rows of 9-10 long, slender spinules.

Mandible (Fig. 3C), palp reduced to small protuberance, bearing 2 slender, naked setae apically; longest seta not reaching to gnathobasal teeth, about 3 times as long as shorter one. Coxal gnathobase well-developed; cutting edge armed with innermost complex of 3 stout teeth and 1 spinous element, middle group of 6 teeth and 5 sharp spinules, and outer group of 1 unipinnate spine and 1 outer subapical unipinnate seta.

Maxillule (Fig. 3D) comprising well developed praecoxa and 2-segmented palp. Praecoxa armed with 4 strong dentate spines inner distally, composed of 3 unipinnate spines basally fused together, and 1 separated posteriormost spine; 6 elements situated along inner face, consisting of 2 strong spinous setae, 1 longest pinnate seta and 3 small, naked setae. Maxillular palp completely divided, about 1.8 times as long as its greatest width, bearing 1 strong bipinnate spine and 2 slender, naked setae distally; endopod small, bearing 1 lateral and 2 apical setae, flanked by 1 proximal seta representing exopod.

Maxilla (Fig. 3E) 4-segmented (praecoxa and coxa fused on posterior surface). Praecoxa with distal endite bearing 1 pinnate and 1 plumose setae apically; proximal endite reduced and unarmed. Coxa, proximal endite represented by 1 short, minutely pinnate seta; distal endite highly mobile, armed with 1 strong, basally fused, spinous element, bearing 2 setules distally, and 1 strong, unipectinate, spinous element. Basis forming a bipinnate claw, with one 1 slender, naked seta at base; 1 strong, unipectinate, spinous element curved, slightly longer than claw. Endopod slightly tapering distally, armed with 3 long, curved, unipinnate, spinous elements and 2 naked setae.

Maxilliped (Fig. 3F) slender, 4-segmented, comprising syncoxa, basis and 2-segmented endopod. Syncoxa, about 2.2 times as long as broad, unornamented; medial margin with 2 endites, bearing 2 and 1 strong, spinous setae, respectively. Basis about 1.7 times as long as broad, with group of spinules halfway outer margin and near outer distal corner; bearing 2 spinous setae inner distally, each with 2 long secondary spinules on posterior margin. First endopodal segment unornamented, with 2 pinnate inner setae; second endopodal segment small and subquadrate, with 1 short, subapical and 2 long, apical setae.

Legs 1-4 (Fig. 4A-D) biramous, both rami 3-segmented. Intercoxal sclerites of legs 1-4 with smooth distal margin, each with 2 lateral lobes, those of leg 1 most pronounced, unarmed with smooth distal margins, not ornamented with any transverse setule or spinule row on both frontal and caudal surfaces. Praecoxal sclerites not expressed. Coxae unornamented, except for spinule row on posterior margin; with 


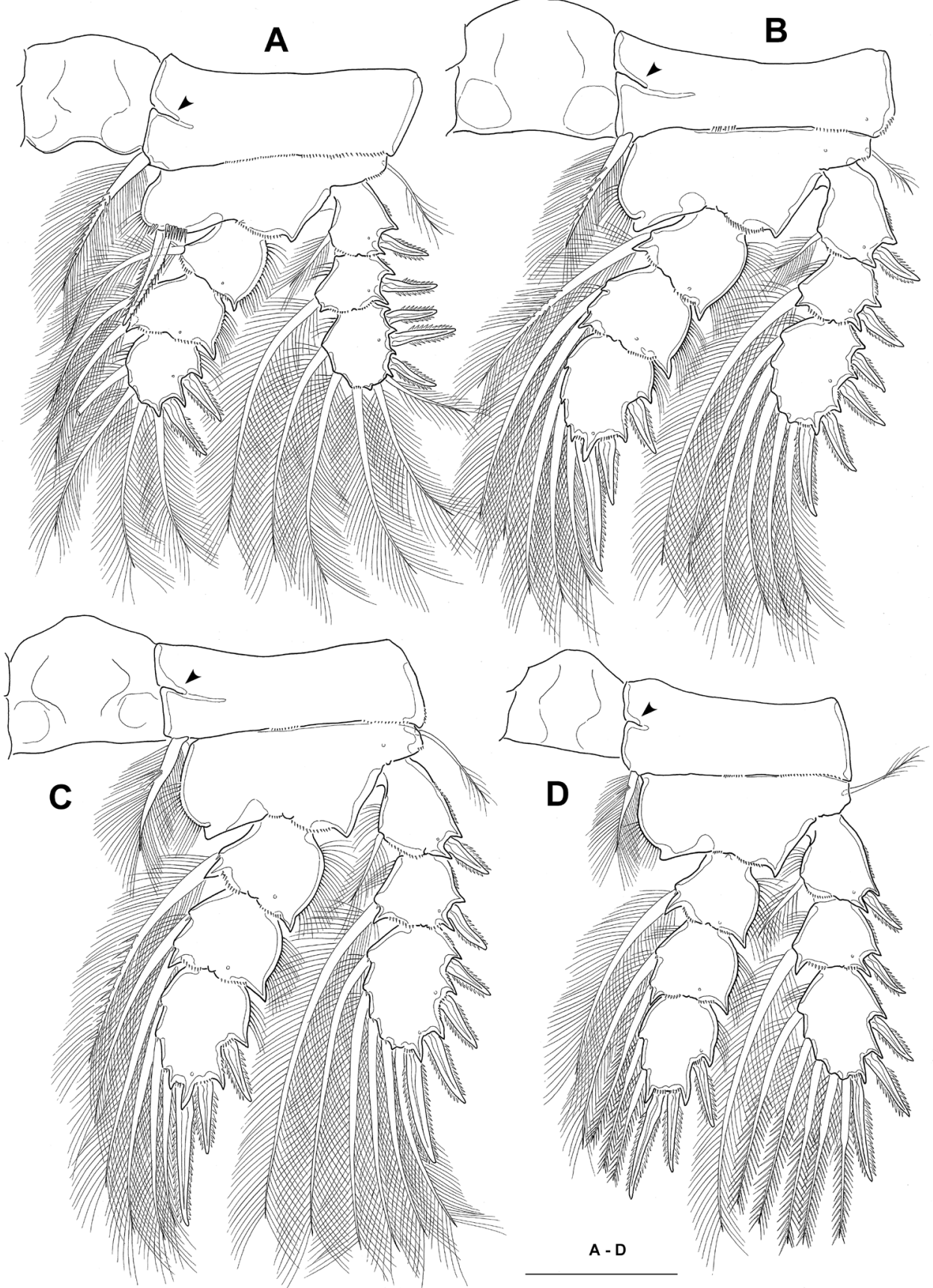

Figure 4. Neocyclops hoonsooi sp. n., female. A leg 1 B leg 2 C leg 3 D leg 4 . All scale bars: $50 \mu \mathrm{m}$. 
transverse internal chitinous ridges originating from medial margins; inner distal plumose seta well developed, but that of leg 4 conspicuously shorter. Exp-3 of legs 1-4 with setal formula 5,5,5,5 and spine formula 3,4,4,3; each leg bearing 2 inner setae on enp-2, and 1 inner seta on enp-1 and exp-1. Leg 1 (Fig. 4A), intercoxal sclerite not broad, its free margin concave; inner distal seta of basis remarkably stout, bipinnate, its tip nearly reaching to distal margin of enp-2. Leg 4 (Fig. 4D), free margin of intercoxal sclerite smooth and nearly straight; enp-3 1.24 times longer than wide; inner distal spine 1.14 times longer than enp-3, 1.36 times longer than outer distal spine; inner setae on exp-3 and enp-3 with swollen proximal half and slender distal half. Seta/spine armature of legs 1-4 as follows:

$\begin{array}{ccccc} & \text { coxa } & \text { basis } & \text { exopod } & \text { endopod } \\ \text { Leg 1 } & 0-1 & 1-1 & \text { I-1, I-1, III,2,3 } & 0-1,0-2, \text { I,I+1,3 } \\ \text { Leg 2 } & 0-1 & 1-0 & \text { I-1, I-1, III,I+1,4 } & 0-1,0-2 \text {, II,I,3 } \\ \text { Leg 3 } & 0-1 & 1-0 & \text { I-1, I-1, III,I+1,3 } & 0-1,0-2, \text { II,I,3 } \\ \text { Leg 4 } & 0-1 & 1-0 & \text { I-1, I-1, II,I+1,4 } & 0-1,0-2, \text { I,II, }\end{array}$

Leg 5 (Fig. 3G) 3-segmented; intercoxal sclerite quadrangular, about twice as long as wide, with nearly straight posterior margin, lacking spinule ornamentation. Coxa clearly defined from fifth pedigerous somite; about twice as wide as greatest length (measured along inner margin); armed with 1 row of minute spinules along distal margin. Basis subtriangular, about 1.5 times wider than long, with 1 plumose seta laterally; 1 cuticular pore present near base of lateral seta. Exopod subpyriform, about twice as long as wide; inner margin tapering abruptly in proximal $1 / 5$, and gradually broadening distally, then slightly narrowing with inner setule row in distal quarter; bearing 2 apical, bipectinate spines flanking 1 long plumose seta apically and 1 subapical spine in distal third of outer margin; inner distal spine 1.2 times longer than outer spine, about 1.4 times as long as lateral spine, about 0.86 times as long as exopod.

Male (allotype): Body (Fig. 1C) $564 \mu \mathrm{m}$ long (mean $572 \mu \mathrm{m}$, standard deviation 10, $n=5$ ). Caudal rami (Fig. 2C, D) 1.36 times longer than wide (conspicuously shorter than in female), with similar setal armature as in female.

Antennule (Fig. 1D) 16-segmented; strongly modified, digeniculate, with major geniculation between segments 14 and 15 and secondary geniculation between segments 8 and 9; segments 14-15 cuticular folds along anterior margin; segment 16 claw-like and curved, with 2 short aesthetascs along posterior margin. Aesthetasc formula: 3,0,0,1,0, $0,0,0,1,0,0,0,1,0,0,2$. Two elements on anterior margins of segments $12-13$ short and spiniform; 1 ventral seta on segment 15 plumose; other setae naked, slender.

Leg 5 (Fig. 2D) 3-segmented, with small intercoxal sclerite; coxa unarmed; basis with slightly swollen inner margin, bearing 1 outer plumose seta, with 1 cuticular pore near base of lateral seta. Exopod about 2.3 times as long as wide; seta/spine armature similar to that in female, except for additional seta on inner margin; allotype showing aberrant asymmetrical spine armature on left side, with outer apical spine being replaced 
by 1 short plumose seta (see Fig. 2D). Leg 6 reduced to operculum with 1 short inner bipinnate spine and 2 plumose setae distally; outer seta slightly longer than inner seta.

Etymology. The proposed specific name is dedicated to the late Professor Hoon Soo Kim in honor of his contribution to the development of invertebrate taxonomy in Korea.

Ecology. This species was found at Holtong beach along the western coast of the Dadohae Oceanic National Park, which is located along south-western coast of the Korean Peninsula. The beach is exposed and fringed with rocks on both sides. The intertidal, coarse to medium sandy sediments contained a little mud. Salinity: 27-32\%o. The new species co-occurred with other interstitial ones: Cerconeotes japonicus (Itô, 1968), Cyclopina spp. (Copepoda), Xenotrichula sp. (Gastrotricha), and Echinoderes sp. (Kinorhyncha).

Remarks. The genus Neocyclops currently accommodates 24 nominal species (Karanovic 2008, Pesce 2015, Walter and Boxshall 2015). Petkovski (1986) proposed a division into two subgenera according to the number of segments in the male leg 5, i.e. 4 segments in the subgenus Protoneocyclops Petkovski, 1986 and 3 segments in the subgenus Neocyclops Gurney, 1927. This classification has not been universally accepted yet (for details, see Karanovic 2008). Based on the presence of a 3-segmented leg 5 in the male, Neocyclops hoonsooi sp. n. might be allocated to the nominotypical subgenus Neocyclops which includes 11 species at present. Nine Neocyclops species which show the 4-segmented condition in the male are currently assigned to the subgenus Protoneocyclops, while four other species are known from females only and can as yet not be attributed to either subgenus: N. parvus (Sewell, 1949), N. magnus (Sewell, 1949), N. improvisus Pleşa, 1973 and N. sharkbayensis Karanovic, 2008.

Neocyclops species typically possess 12 -segmented antennules in the female but a few members are known to show fewer segments: 11-segmented in $N$. improvisus and $N$. geltrudeae Pesce \& Galassi, 1993, 10-segmented in N. petkovskii De Laurentiis, Pesce \& Halse, 1997, and only 8-segmented in N. salinarum (Gurney, 1927). Neocyclops hoonsooi sp. n. shares the 10-segmented condition with N. petkovskit, showing traces of subdivision in compound segments 3 and 4 . Neocyclops hoonsooi sp. n. also shares with $N$. petkovskii an exopodal seta on the antenna, which is absent in $N$. parvus, $N$. medius Herbst, 1955, N. affinis (Pleşa, 1961), N. improvisus, N. australiensis Karanovic, 2008, and $N$. dussarti Karanovic, 2008 [= nomen novum for $N$. affinis Dussart, 1974, a junior homonym of $N$. affinis (Pleşa, 1961), for details, see Karanovic 2008: 262].

The new species is most characteristic in having large scar-like integumental ridges originating from the medial margins of the coxae in all swimming legs. The transverse chitinized reinforcements are very conspicuous, and consistently occurred in all specimens examined. Similar structures have been illustrated for three species that were recently described from Australia by Karanovic (2008): figure 54A and D for leg 1 and leg 4 of $N$. australiensis, figures 58D and 59B for leg 1 and leg 4 of $N$. sharkbayensis, and figure 61C for leg 3 of $N$. trajani Karanovic, 2008. However, all of them are less pronounced, and illustrated as small open-circles or ovals in close connection to the medial margin of the coxae, which showed quite different patterns from those of the new species.

The new species is also unusual in bearing a small setule on the anteroventral surface of the caudal ramus in both sexes. This setule is here identified as the anterolateral 
accessory seta I. As far as we can ascertain, it was recorded only once before in the genus Neocyclops, i.e. in the description of the female caudal ramus of $N$. pilbarensis Karanovic, 2008, where it was interpreted as a "sensillum at anterior part ventrally". While the caudal seta I is rarely expressed and usually lacking in members of the Cyclopoida, it can sometimes be quite conspicuous in some marine, and especially ancestral, genera, such as Heterocyclopina Pleşa, 1968. Karanovic (2008, fig. 49A, B) interpreted a similar structure as the "lateral sensillum" in his description of Abrsia misophrioides but did not consider the possibility of it being one of the caudal setae. Based on positional homology we believe that the "sensillum" observed in N. pilbarensis and A. misophrioides represents the vestigial caudal seta I and is homologous with the minute seta described in $N$. hoonsooi sp. n.

Another unusual characteristic of $N$. hoonsooi sp. n. is the very short caudal ramus, being slightly less than 1.7 times as long as wide. Caudal rami of Neocyclops species are generally more than twice as long as wide, being about 2.0-2.5 times in $N$. affinis, $N$. parvus, $N$. australiensis and $N$. ferrarii Rocha, 1995, 2.7-3.0 times in $N$. magnus and $N$. vicinus (Herbst, 1955), and even reaching to 3.5-4.0 times in $N$. remanei (Herbst, 1952). However, in a few species the caudal ramus is much shorter, and less than twice as long as wide, being about 1.8-2.0 times in $N$. medius and $N$. dussarti, and slightly less than 1.7 times in $N$. hoonsooi sp. n. Two genuinely interstitial species from beaches in southern Australia, have extremely short caudal rami (1.5 times in N. tropicus Karanovic, 2008, and 1.3 times in $N$. trajani), however, these species differ clearly from $N$. hoonsooi $\mathrm{sp}$. $\mathrm{n}$. by the much smaller body size (546-565 $\mu \mathrm{m}$ long), the 12-segmented antennule, the presence of 3 setae on the mandibular palp, and the very long dorsal caudal seta (1.5-2.4 times longer than caudal rami). The caudal seta VII in $N$. hoonsooi sp. n. is slightly shorter or nearly as long as the caudal ramus. This condition is shared with $N$. ferrarii, $N$. improvisus, $N$. magnus, $N$. mediterraneus (Kiefer, 1960), N. remanei and N. vicinus, while most other species have a much longer dorsal seta (more than twice longer than the caudal ramus): N. geltrudeae, N. pilbarensis, N. sharkbayensis and N. tropicus. Neocyclops papuensis Fiers, 1986 clearly differs from all its congeners, including the present new species, by bearing an extremely short dorsal seta ( 0.4 times as long as the caudal ramus). Seta VI (innermost caudal seta) of $N$. hoonsooi sp. n. is much longer than seta III (outermost caudal seta), and thus differs from those species that display the reverse condition (seta III longer than seta VI) such as $N$. affinis, N. vicinus, N. improvisus, $N$. monchenkoi Karanovic, 2008 and $N$. australiensis.

Neocyclops hoonsooi sp. n. displays the typical seta/spine armature pattern on legs 1-4 found in the majority of species in the genus Neocyclops. The setal formula of the third exopodal segments of the new species is 5,5,5,5, which differs from the 5,5,5,4 pattern in $N$. herbsti Petkovski, 1986 and the 4,5,5,5 condition in $N$. wellsi Petkovski, 1986. The spine formula of the third exopodal segments of $N$. hoonsooi sp. n. is 3,4,4,3, and differs only from the 2,4,4,3 pattern of $N$. sharkbayensis. The setal formula on the distal endopodal segments of the new species is 4,3,3,2, and differs from the 4,3,4,2 pattern displayed by $N$. affinis, $N$. dussarti and N. improvisus (Pleşa 1961, 1973, Dus- 
sart 1974). The spine formula of the third endopodal segments of $N$. hoonsooi sp. n. is 2,3,3,3, and differs from the 2,3,2,3 condition observed in N. monchenkoi. Neocyclops species, including the new species, typically bear two setae along the inner margin of the second endopodal segment of all swimming legs; the only exception to this rule is $N$. sharkbayensis which displays a single seta only on legs 1-2.

Taking into consideration the characters mentioned above, $N$. hoonsooi sp. n. appears to be most similar to $N$. vicinus, described from the Brazilian coast, and $N$. petkovskii, from Australia. All three species share a large body size (more than $750 \mu \mathrm{m}$ long), the presence of an exopodal seta on the antenna, two setae on the mandibular palp, the same seta/spine armature on the third endopodal segment of leg 3 (3 setae + 3 spines), and the fairly long inner distal spine on the third endopodal segment of the female leg 4 . However, $N$. hoonsooi sp. n. clearly differs from $N$. vicinus by the follow-

Table I. Character comparison among the allied species of $N$. hoonsooi sp. n.

\begin{tabular}{|c|c|c|c|c|c|c|c|}
\hline & affinis & australiensis & improvisus & monchenkoi & petkovskii & vicinus & hoonsooi sp. n. \\
\hline q, body length $(\mu \mathrm{m})$ & $390-439$ & 731 & $396-488$ & $720-1,110$ & 765 & 750 & 830 \\
\hline $\begin{array}{l}\text { P, antennule, } \\
\text { no. of segments }\end{array}$ & 12 & 12 & 11 & 12 & 10 & 12 & 10 \\
\hline Antenna, exp seta & absent & absent & absent & present & present & present & present \\
\hline $\begin{array}{c}\text { Mandible, } \\
\text { no. of setae on palp }\end{array}$ & 1 & 3 & 1 & 2 & 2 & 2 & 2 \\
\hline $\begin{array}{l}\text { Caudal rami, } \\
\mathrm{L} / \mathrm{W} \text { ratio, }+ \text { }\end{array}$ & $2.2-2.6$ & 2.5 & $1.8-2.0$ & $2.7-3.5$ & 2.4 & -3 & $1.6-1.7$ \\
\hline $\begin{array}{c}\text { Length ratio, } \\
\text { caudal setae VI/III }\end{array}$ & -1 & 0.7 & 0.9 & -0.9 & -1 & $0.9-1.0$ & $1.5-1.6$ \\
\hline $\begin{array}{c}\text { Length ratio, } \\
\text { caudal setae VII/VI }\end{array}$ & -3 & -3.5 & -2.2 & -3 & $\geq 1$ & 1.4 & $-2 / 3$ \\
\hline $\begin{array}{c}\text { Length ratio, } \\
\text { caudal seta V/ramus }\end{array}$ & -1.6 & -1.4 & -1 & -1.3 & -0.7 & -0.9 & -0.9 \\
\hline $\begin{array}{c}\text { Leg } 3 \text { enp-3 armature } \\
\text { formula }\end{array}$ & $4, \mathrm{III}$ & 3,III & 4,III & 3,II & 3,III & 3,III & 3,III \\
\hline $\begin{array}{l}\text { Leg 4, length ratio of } \\
\text { inner spine/enp-3 }\end{array}$ & $1.5-1.8$ & -1.3 & 1.6 & $1.6-1.7$ & 1.2 & -1.4 & -1.2 \\
\hline $\begin{array}{l}\text { P leg } 5 \text { exp, length ratio } \\
\text { of inner/outer spines }\end{array}$ & $1.2-1.5$ & -1.1 & 1.2 & -1.2 & 0.9 & 1.1 & 1.2 \\
\hline $\begin{array}{l}\text { P leg } 5 \text { exp, length ratio } \\
\text { of inner/lateral spines }\end{array}$ & 1.3 & 1.5 & 1.3 & -1.3 & 0.9 & 1.3 & 1.4 \\
\hline $\begin{array}{l}\text { q leg } 5 \text {, length ratio of } \\
\text { inner distal spine/exp }\end{array}$ & $0.9-1$ & -1.2 & 0.7 & $0.7-0.8$ & 0.5 & 0.86 & 0.86 \\
\hline leg 5, no. of segments & 3 & $3 / 4^{\dagger}$ & - & 3 & 4 & 3 & 3 \\
\hline Distribution & $\begin{array}{c}\text { Ghana'; } \\
\text { West Indies } \\
\end{array}$ & Australia ${ }^{3}$ & $\mathrm{Cuba}^{4}$ & Black Sea ${ }^{5}$ & Australia $^{6}$ & Brazil $^{7}$ & Korea $^{8}$ \\
\hline
\end{tabular}

${ }^{\dagger}$ incomplete division

References: ${ }^{1}$ Pleşa (1961), ${ }^{2}$ Pesce (1985), ${ }^{3}$ Karanovic (2008), ${ }^{4}$ Pleşa (1973), ${ }^{5}$ Pleşa (1964) \& Monchenko (1974), ${ }^{6}$ De Laurentiis et al. (1997) \& Karanovic (2008), ${ }^{7}$ Herbst (1955) \& Lotufo and Rocha (1993), ${ }^{8}$ present study. 
ing characters: (1) 10-segmented antennule (vs 12 segments in N. vicinus); (2) shorter caudal rami (less than 1.7 times as long as wide, while about three times longer in $N$. vicinus); and (3) much shorter dorsal caudal seta VII (about 2/3 times shorter than inner caudal seta VI, while 1.4 times longer in $N$. vicinus), and much longer inner caudal seta VI (more than 1.5 times longer than outer caudal seta III, while slightly shorter than outer one in $N$. vicinus). Furthermore, $N$. hoonsooi sp. n. also clearly differs from $N$. petkovskii by the much shorter caudal rami (vs 2.4 times as long as wide in $N$. petkovskii), the shorter inner distal spine on the female leg 5 (vs slightly shorter than the outer distal and lateral spines, and about half the length of the exopod in $N$. petkovskii), and the 3-segmented leg 5 in male (vs 4-segmented in $N$. petkovskii). Table 1 shows the character comparison between the new species from South Korea and its closest allies.

\section{Geographical records and a key to Neocyclops species from the Indo-Pacific Ocean}

Pacific Ocean: from Papua New Guinea, N. papuensis Fiers, 1986 by Fiers (1986).

Indian Ocean: from Australia, N. australiensis Karanovic, 2008, N. sharkbayensis

Karanovic, 2008, N. trajani Karanovic, 2008 and N. tropicus Karanovic, 2008 by Karanovic (2008); from West Australia, N. petkovskii De Laurentiis, Pesce \& Halse, 1997 by De Laurentiis et al. (1997); from Maldive Archipelago, N. parvus (Sewell, 1949) and N. magnus (Sewell, 1949) by Sewell (1949); from Red Sea, N. herbsti Petkovski, 1986, and from Mozambique, N. wellsi Petkovski, 1986 by Petkovski (1986); from Egypt, N. salinarum (Gurney, 1927) by RBINS (2015).

Female antennule 8-segmented

N. salinarum

Female antennule 10-segmented .2

Female antennule 12-segmented

Caudal rami not more than 1.7 times as long as wide in female; male leg 5 3-segmented N. hoonsooi sp. n. Caudal rami about 2.4 times as long as wide in female; male leg 5 4-segmented N. petkovskii Caudal rami less than 1.5 times as long as wide in female. . .4 Caudal rami about 2-2.7 times as long as wide in female 5 Caudal rami 3-3.5 times as long as wide in female N. papuensis Dorsal caudal seta VII less than twice as long as ramus N. trajani

Dorsal caudal seta VII more than twice as long as ramus N. tropicus Exopodal seta on antenna lacking.... 6 Exopodal seta on antenna present ..8 Inner caudal seta VI longer than outer caudal seta III N. parvus Inner caudal seta VI shorter than outer caudal seta III .7 
- $\quad$ Enp-2 of legs 1-3 with 2 inner setae; exp-3 of leg 1 with 3 spines

\section{Acknowledgements}

We are much obliged to Professor Rony J. Huys (The Natural History Museum, London) for his critical review, and also appreciate an anonymous reviewer for the critical comments that greatly improved the manuscript. We are deeply grateful to Dr. Janet W. Reid (Virginia Museum of Natural History, USA) and Dr. Chad Walter for providing many references. This work was supported in part by the research grant of Daegu University, Korea in 2011.

\section{References}

Chang CY (2011) First record of the genus Cyclopinoides (Copepoda, Cyclopoida, Cyclopinidae) from the Pacific. Animal Cells and Systems 15(1): 63-72.

Chang CY (2013) A new species of Cletocamptus Copepoda (Harpacticoida, Canthocamptidae) from salt marshes in Korea. Animal Systematics, Evolution and Diversity 29: 227-237.

Chang CY (2014) Two new records of monstrilloid copepods (Crustacea) from Korea. Animal Systematics, Evolution and Diversity 30: 206-214.

De Laurentiis P, Pesce GL, Halse SA (1997) Discovery of the first representative of the genus Neocyclops Gurney in Australia, and description of Neocyclops (Neocyclops) petkovskii n. sp. (Copepoda, Halicyclopinae). Bulletin Zoölogisch Museum, Universiteit van Amsterdam 16(3): 15-19.

Dussart BH (1974) Contribution à l'étude des Copépodes des eaux douces d'Éthiopie. Bulletin de l'Institut français d'Afrique Noire 36: 92-116.

Fiers F (1986) New and interesting copepods (Crustacea, Copepoda) from brackish waters of Laing Island (Northern Papua New Guinea). Bulletin de l'Institut Royal des Sciences naturelles de Belgique, Biologie 56: 99-120.

Herbst HV (1955) Cyclopoida Gnathostoma (Crustacea, Copepoda) von der brasilianischen Atlantikküste. Kieler Meeresforschungen 11(2): 214-229.

Huys R, Boxshall GA (1991) Copepod Evolution. The Ray Society, London, 468 pp.

Karanovic T (2008) Marine interstitial Poecilostomatoida and Cyclopoida (Copepoda) of Australia. Crustaceana Monographs 9: 1-336.

Karanovic T (2014) On the phylogeny of Euryteinae (Crustacea, Copepoda, Cyclopoida), with description of one new species from Korea. Zoologischer Anzeiger 253(6): 512-525.

Lotufo GR, Rocha CEF (1993) Neocyclops Gurney from Brazilian sandy beaches (Copepoda: Cyclopoida). Bijdragen tot de Dierkunde 63(3): 163-172. 
Monchenko VI (1974) Shchelepnoroti tsiklopodiny, tsiklopi (Cyclopidae). Fauna Ukrainy, volume 27, issue 3. Vidavnitstvo Naukova Dumka, Kiev, 452 pp.

Pesce GL (1985) Amsterdam Expeditions to the West Indian Islands, Report 45. Cyclopids (Crustacea, Copepoda) from West Indian groundwater habitats. Bijdragen tot de Dierkunde 55(2): 295-323.

Pesce GL (2015) Cyclopoida: Halicyclopinae Kiefer, 1927: Neocyclops Gurney, 1927. Copepod Web Portal, http://www.luciopesce.net/copepods/neocy.htm [accessed on 2015-03-15]

Petkovski TK (1986) Zur Taxonomie des Genus Neocyclops Gurney 1927 (Crustacea, Copepoda, Cyclopoida). Acta Musei Macedonici Scientiarum Naturalium, Skopje 18(2/148): 27-46.

Pleşa C (1961) New cyclopoids (Crustacea, Copepoda) of the interstitial fauna from the beaches of Ghana. Journal of the West African Science Association 7(1): 1-13.

Pleşa C (1964) Étude sur la faune interstitielle litorale de la mer Noire. III. Résultats préliminaires des recherches sur la côte roumaine, avec aperçu spécial sur les Cyclopoides Gnathostomes (Crustacea, Copepoda). Vie et Milieu 14(4): 775-813.

Pleşa C (1973) Un nouveau cyclopide interstitiel de la Mer des Caraïbes: Neocyclops improvisus sp. n. (Crustacea, Copepoda). Résultats des Expéditions biospéologiques cubano-roumaines à Cuba 1: 119-122.

RBINS (Royal Belgian Institute of Natural Sciences) (2015) RBINS collections. GBIF ID 439781611. http://www.gbif.org/occurrence/439781611 [accessed on 2015-03-30]

Sewell RBS (1949) The littoral and semi-parasitic Cyclopoida, Monstrilloida and Notodelphyoida. Scientific Reports of the John Murray Expedition 1933-34 9(2): 17-199.

Shirayama Y, Kaku T, Higgins RP (1993) Double-sided microscopic observation of meiofauna using an HS-slide. Benthos Research 44: 41-44.

Tran DL, Chang CY (2013) Graeteriella (Graeteriella) longifurcata n. sp., a stygobitic cyclopoid species (Copepoda: Cyclopoida: Cyclopidae) from Central Vietnam. Proceedings of the biological Society of Washington 126(3): 245-258.

Walter TC, Boxshall G (2015) Neocyclops Gurney, 1927. World of Copepods database, http:// www.marinespecies.org/copepoda/aphia.php?p=taxdetails\&id=106434 [accessed on 2015-02-21] 